\title{
NITROGEN FRACTIONS AND AMINO ACID CONTENT IN ALFALFA AND RED CLOVER IMMEDIATELY AFTER CUTTING AND AFTER WILTING IN THE FIELD*
}

\author{
Cezary Purwin ${ }^{1}$, Maja Fijałkowska ${ }^{1}$, Barbara Pysera ${ }^{1}$, \\ Krzysztof Lipiński ${ }^{1}$, Stanisław Sienkiewicz ${ }^{2}$, \\ Dariusz Piwczyński ${ }^{3}$, Natalia Puzio ${ }^{1}$ \\ ${ }^{1}$ Chair of Animal Nutrition and Feed Science \\ ${ }^{2}$ Chair of Agricultural Chemistry and Environment Protection \\ University of Warmia and Mazury in Olsztyn \\ ${ }^{3}$ Chair of Genetics and General Animal Breeding \\ University of Agriculture and Life Science in Bydgoszcz
}

\begin{abstract}
The aim of this study was to determine the composition of nitrogen fractions in alfalfa and red clover, which differ in proteolytic activity, and to evaluate the effect of wilting on changes in nitrogen fractions in alfalfa and red clover herbage. Total nitrogen was divided into protein and non-protein nitrogen, and the amino acid profile of protein was analyzed. Buffer-soluble nitrogen (BSN), including buffer-soluble protein nitrogen (BSPN) and non-protein buffer-soluble nitrogen (NPBSN), was determined. The NPBSN fraction was further subdivided into peptide nitrogen, amino acid nitrogen, neutral detergent-insoluble nitrogen (NDIN) and acid detergent-insoluble nitrogen (ADIN). Wilting in the field to 40\% dry matter content (the swath was tedded once) did not reduce the total nitrogen content of alfalfa and red clover herbage, although it affected the concentration of the BSNfraction, in particular NPBSN, and free amino acid nitrogen. During alfalfa wilting, the soluble protein content decreased and the concentrations of non-protein nitrogen compounds increased, mostly due to an increase in free amino acid nitrogen. A reverse trend was observed during red clover wilting - the concentrations of non-protein nitrogen compounds decreased and soluble protein content increased. A decrease was also noted in peptide nitrogen, NDIN and ADIN. Wilting of alfalfa and red clover had no adverse effect on the amino acid profile of protein. The concentrations of essential amino acids that limit milk protein synthesis, i.e. Lys, Met, His and Arg, did not decrease. Legume wilting in the field contributes to an increase in the concentrations of soluble nitrogen in the plant material intended for ensiling.
\end{abstract}

Key words: alfalfa, red clover, nitrogen fractions, amino acids, wilting.

dr hab. Cezary Purwin, prof. UWM, Chair of Animal Nutrition and Feed Science, University of Warmia and Mazury, Oczapowskiego 5, 10-718 Olsztyn, Poland, e-mail: purwin@uwm.edu.pl * Supported by the State Committee for Scientific Research, Grant No. N N311 234238. 


\title{
ZAWARTOŚĆ FRAKCJI AZOTOWYCH ORAZ AMINOKWASÓW W ZIELONKACH Z LUCERNY I KONICZYNY CZERWONEJ BEZPOŚREDNIO PO SKOSZENIU ORAZ PO PODSUSZENIU NA POKOSACH
}

\begin{abstract}
Abstrakt
Celem pracy była charakterystyka składu frakcji azotowych w zielonkach z lucerny i koniczyny czerwonej, surowcach roślinnych różniących się potencjałem proteolitycznym, oraz ocena wpływu podsuszania na skład frakcji azotowych w tych zielonkach. Rozdzielono azot ogólny na azot białkowy i azot niebiałkowy oraz określono skład aminokwasowy białka. Ponadto określono związki azotowe rozpuszczalne w buforze (BSN), rozdzielono je na białkowe zwiąki azotowe rozpuszczalne w buforze (BSPN) i niebiałkowe związki azotowe rozpuszczalne w buforze (NPBSN). We frakcji NPBSN wyodrębniono azot peptydowy oraz azot aminokwasowy, wydzielono także związki azotowe o niskiej rozpuszczalności (azot nierozpuszczalny w neutralnym detergencie -NDIN) i całkowicie nierozpuszczalne (azot nierozpuszczalny w kwaśnym detergencie-ADIN). Podsuszenie na pokosach do $40 \%$ suchej masy z zastosowaniem jednokrotnego zabiegu przetrzasania nie spowodowało ubytku azotu ogólnego w zielonkach z lucerny i koniczyny czerwonej, natomiast wpłynęło na koncentrację całej frakcji rozpuszczalnej w buforze, szczególnie jej części niebiałkowej, oraz azotu w formie wolnych aminokwasów. W czasie podsuszania zielonki z lucerny malał udział białek rozpuszczalnych, natomiast wzrastał udział związków niebiałkowych, przede wszystkim za sprawą wzrostu azotu wolnych aminokwasów. W koniczynie czerwonej w trakcie podsuszania - odwrotnie niż w lucernie - malała frakcja związków niebiałkowych, natomiast wzrastała frakcja łatwo rozpuszczalnych białek, zaobserwowano wyraźny ubytek azotu w formie peptydowej oraz frakcji trudno rozpuszczalnych i nierozpuszczalnych. Podsuszenie zielonek z lucerny i koniczyny czerwonej nie pogorszyło profilu aminokwasowego białka. Nie stwierdzono ubytku aminokwasów egzogennych limitujących syntezę białka mleka, tj: Lys, Met, His, Arg. Zabieg podsuszania zielonek z motylkowatych na pokosach wpływa na zwiększenie udziału form rozpuszczalnych azotu w surowcu przed zakiszaniem.
\end{abstract}

Słowa kluczowe: lucerna, koniczyna czerwona, frakcje azotowe, aminokwasy, podsuszanie.

\section{INTRODUCTION}

Due to high prices of protein supplements, in particular soybean meal, recent years have witnessed a revival of interest in high-protein roughages such as legume herbage and silage. Alfalfa and red clover are most widely used fodder legumes in the moderate climate zone (ŻUK-GoŁASZEWSKA et al. 2010). Legumes have a high total protein content, a low water-soluble carbohydrate (WSC) content and high buffering capacity, which makes them difficult to ensile (PuRwin et al. 2011). Alfalfa and red clover need to be wilted before ensiling to improve silage quality. Water loss during wilting contributes to an increase in the osmotic pressure in plant cells. As a result, water contained in cells is unavailable to clostridia, thus reducing the risk of their growth, whereas a higher sorption capacity supports the proliferation of lactic acid bacteria. Wilting encourages lactic acid fermentation, minimizes proteolysis and inhibits the growth of butyric acid bacteria responsible for secondary fermentation and silage quality deterioration (DAwson et al. 1999). Proteolysis begins in plant cells after cutting. The percentage of protein that is hydrolyzed during ensiling is determined by the proteolytic potential, i.e. 
protease activity and substrate availability. Alfalfa has the highest proteolytic potential. Red clover contains high levels of polyphenol oxidase (PPO), which protects protein against proteolysis. Studies on the technology of bale silage production, conducted to date, have focused on the effect of herbage wilting and chemical additives on the rate of fermentation, aerobic stability and microbiological quality of silage. The effect of wilting on nitrogen fractions and amino acids in forages has been analyzed under laboratory conditions (Papadopoulos, McKersie 1983, Meesman et al. 1994, Guo et al. 2008). Cavallarin et al. (2005) investigated the effect of wilting in the field on the composition of nitrogen fractions and amino acid profile of sainfoin. ARRIGO (2006) studied the effect of wilting on the amino acid profile of mixtures of different grasses and grass and clover. However, little attention has been paid to the effect of wilting on changes in the composition of nitrogen fractions and amino acid in legumes.

The aim of this study was to determine the composition of nitrogen fractions in alfalfa and red clover, which differ in proteolytic activity, and to evaluate the effect of wilting on changes in nitrogen fractions in alfalfa and red clover herbage. Total nitrogen was divided into protein nitrogen and non-protein nitrogen. McDougall's buffer (simulating ruminant saliva) was used to determine buffer-soluble nitrogen (BSN), including buffer-soluble protein nitrogen (BSPN) and non-protein buffer-soluble nitrogen (NPBSN). The NPBSN fraction was further subdivided into peptide nitrogen, amino acid nitrogen, neutral detergent-insoluble nitrogen (NDIN) and acid detergent-insoluble nitrogen (ADIN).

\section{MATERIAL AND METHODS}

The study was conducted in 2009 at the Agricultural Experiment Station of the University of Warmia and Mazury in Olsztyn, located in Łężany. The experimental plant materials comprised the first cut herbage of alfalfa (cv. Alba) and red clover (cv. Nike) in the second year of growing. Nitrogen top-dressing was not applied, and phosphorus and potassium were applied at $80 \mathrm{~kg} \mathrm{P}_{2} \mathrm{O}_{5}$ and $100 \mathrm{~kg} \mathrm{~K} \mathrm{~K}_{2}$ per ha. Alfalfa and red clover were harvested at the beginning of flowering. Primary herbage samples were collected at four locations within each field, from the complete depth of the swath, along the length of $0.3 \mathrm{~m}$, and were combined to obtain bulk/consolidated samples. Average samples were taken from each location (4 n). Samples were collected immediately after cutting and after 36-hour wilting (the swath was tedded once), each time from the same part of the field. In the field, samples were placed in liquid nitrogen containers and were stored at $-25^{\circ} \mathrm{C}$. PPO activity was determined in selected samples immediately after thawing. The remaining samples were dried at $40^{\circ} \mathrm{C}$ using Binder FED 115 drying ovens with forced convection, and were ground in a Retsch SK 100 cross beater mill to 
the particle size of $1 \mathrm{~mm}$. Changes in the following nitrogen fractions during ensiling were determined: protein nitrogen, buffer-soluble nitrogen (BSN), including buffer-soluble protein nitrogen (BSPN), peptide nitrogen, amino acid nitrogen,ammonium nitrogen, neutral detergent-insoluble nitrogen (NDIN) and acid detergent-insoluble nitrogen (ADIN).

Immediately after cutting and after wilting, samples were assayed for: proximate chemical composition - by standard methods (AOAC, 2005), WSC - by the anthrone method (THOMAs 1977), buffering capacity - as described by McDonald and Henderson (1962), NDF, ADF and ADL - by the method proposed by VAN SoEst et al. (1991), PPO activity - according to HALASIŃsKA et al. (2001), protein nitrogen - with the use of trichloroacetic acid (TCA), as described by Guo et al. (2008), BSN - using McDougall's buffer, according to the procedure of Hedqvist and Uden (2006). Fodder samples (1.6 g) were mixed with $40 \mathrm{ml}$ of McDougall's buffer (adjusted to $\mathrm{pH}$ 6.8), and were incubated for one hour at $39^{\circ} \mathrm{C}$ in a water bath shaker. Samples were centrifuged at $3000 \mathrm{~g}^{-1}$ for 10 minutes. The protein nitrogen content of the supernatant was determined by the Kjeldahl method. The BSN fraction was subdivided into BSPN, peptide nitrogen, amino acid nitrogen and ammonia nitrogen. To determine BSPN, $20 \mathrm{ml}$ BSN extract was mixed with $2 \mathrm{ml}$ of TCA, and the mixture was incubated for one hour in ice bath at $2-3^{\circ} \mathrm{C}$. Samples were centrifuged at $5000 \mathrm{~g}^{-1}$ for 25 minutes at $4^{\circ} \mathrm{C}$ in a fixed-angle rotor centrifuge. The supernatant was analyzed using the same procedure as described above for BSN. BSPN was calculated as the difference between BSN and TCA-soluble nitrogen. Peptide nitrogen was calculated as the difference between alpha-amino nitrogen in hydrolyzed TCA-soluble nitrogen and free amino acid nitrogen (HEDQVIST, UdEN 2006). Amino acid nitrogen was measured as total free amino acids determined in samples deproteinized with TCA, using an amino acid analyzer equipped with a lithium column (WINTERs et al. 2002). The amino acid content of hydrolyzates was determined with the use of the AAA 400 INGOS amino acid analyzer with a sodium column. The tryptophan content was determined according to Standard PN-EN ISO 13904: 2005.

The results were processed statistically by two-way ANOVA. A model describing chemical composition, buffer capacity, PPO activity, composition of nitrogen fractionsof herbageand changes in amino acid concentrations accounted for the effects of legume species, wilting and the species $\mathrm{x}$ wilting interaction. The significance of differences between means (species and wilting groups) was estimated by the Duncan's test.

\section{RESULTS AND DISCUSSION}

The effect of forage species and wilting on the chemical composition of alfalfa and red clover herbage is presented in Table 1 . Significant $(p<0.01)$ differences were found between alfalfa and red clover in the content of dry 
Chemical composition ( $\left.\mathrm{g} \mathrm{kg}^{-1} \mathrm{~d} . \mathrm{m}.\right)$, buffer capacity ( $\left.\mathrm{ml} \mathrm{kg}{ }^{-1} \mathrm{~d} . \mathrm{m}.\right)$,

PPO activity (J kg-1 d.m.) of herbage

\begin{tabular}{|c|c|c|c|c|c|c|c|c|}
\hline \multirow{2}{*}{ Item } & \multicolumn{2}{|c|}{ Alfalfa } & \multicolumn{2}{|c|}{ Red clover } & \multirow{2}{*}{ SEM } & \multicolumn{2}{|c|}{ Treatment } & \multirow{2}{*}{$\mathrm{SxW}$} \\
\hline & fresh & wilted & fresh & wilted & & $\mathrm{S}$ & $\mathrm{W}$ & \\
\hline Dry matter $\left(\mathrm{g} \mathrm{kg}^{-1}\right)$ & 188 & 429 & 204 & 423 & 7.13 & $* *$ & $* *$ & $\mathrm{~ns}$ \\
\hline Crude ash & 70.8 & 78.6 & 65.6 & 86.1 & 2.70 & $* *$ & $* *$ & ns \\
\hline NDF & 443 & 462 & 438 & 456 & 9.01 & $* *$ & $*$ & ns \\
\hline $\mathrm{ADF}$ & 376 & 383 & 350 & 378 & 4.17 & $* *$ & $*$ & $\mathrm{~ns}$ \\
\hline ADL & 82.4 & 86.8 & 62.0 & 69.2 & 5.78 & $* *$ & $* *$ & $\mathrm{~ns}$ \\
\hline WSC & 70.3 & 58.9 & 120 & 102 & 2.86 & $* *$ & $* *$ & ns \\
\hline Buffer capacity & 12.8 & 10,3 & 8.26 & 7.46 & 0.59 & $* *$ & $* *$ & $\mathrm{~ns}$ \\
\hline PPO activity & 82 & 11 & 185 & 56 & 15.8 & $* *$ & $* *$ & $* *$ \\
\hline
\end{tabular}

$\mathrm{S}$ - species; W- wilting; SEM - standard error of the mean; ns - not significant; ${ }^{* *}$ significant at $P<0.01 ;{ }^{*}$ significant at $P<0.05$

matter, crude ash, structural and water-soluble carbohydrates, buffering capacity and PPO activity. Our findings confirm the results of previous research (PURwIN et al. 2010) showing that alfalfa is characterized by lower concentrations of water-soluble carbohydrates, higher buffering capacity and a faster rate of lignification, compared with red clover. In both legume species, wilting contributed to a decrease in WSC levels and buffering capacity $(p<0.01)$, and an increase in the content of crude ash, NDF, ADF $(p<0.05)$, ADL $(p<0.01)$ and PPO activity $(p<0.01)$. The increase in the content of crude ash and structural carbohydrates, observed during wilting, is relative and results from WSC loss during respiration processes (MUCK 1988). The buffering capacity decreased due to reduced intracellular activity, in particular reduced concentrations of short-chain fatty acids in the cytoplasm (Krebs cycle); the buffering capacity of short-chain fatty acids is substantially higher than that of protein (McDonALD et al. 1991). The decrease in PPO activity was related to changes in osmolarity in the cells of alfalfa and red clover plants (GIVEns, RulQuin 2004).

The total nitrogen content of herbage dry matter was higher $(p<0.01)$ in alfalfa than in red clover (Table 2). Wilting had no influence on the total nitrogen content, which points to a minimal mechanical loss during tedding and raking (SlotTner, Bertilsson 2006). Protein nitrogen had a higher $(p<0.05)$ share of total nitrogen in fresh and wilted red clover (765 and $695 \mathrm{~g} \mathrm{~kg}^{-1}$ total nitrogen) than in alfalfa (702 and $642 \mathrm{~g} \mathrm{~kg}^{-1}$ total nitrogen). Irrespective of forage species, wilting decreased (by ca 9\%) the protein/total nitrogen ratio in comparison with green herbage $(p<0.01)$. In a study by Papadopoulos and McKersie (1983), wilting of the first cut herbage of alfalfa and red clover for 6 and 24 hours led to a decrease in the protein nitrogen 
Composition of nitrogen fractions ( $\mathrm{g} \mathrm{kg}^{-1}$ total nitrogen) of herbage

\begin{tabular}{|c|c|c|c|c|c|c|c|c|}
\hline \multirow{2}{*}{ Item } & \multicolumn{2}{|c|}{ Alfalfa } & \multicolumn{2}{|c|}{ Red clover } & \multirow{2}{*}{ SEM } & \multicolumn{2}{|c|}{ Treatment } & \multirow{2}{*}{$\mathrm{SxW}$} \\
\hline & fresh & wilted & fresh & wilted & & $\mathrm{S}$ & $\mathrm{W}$ & \\
\hline Total nitrogen ( $\mathrm{g} \mathrm{kg}^{-1} \mathrm{~d} . \mathrm{m}$.) & 29.6 & 28.0 & 26.5 & 26.5 & 0.37 & $* *$ & ns & ns \\
\hline Protein nitrogen & 702 & 642 & 765 & 695 & 20.1 & * & $* *$ & ns \\
\hline BSN & 272 & 255 & 180 & 178 & 3.19 & $* *$ & $* *$ & $* *$ \\
\hline NPBSN & 109 & 143 & 123 & 114 & 3.59 & $* *$ & $* *$ & $* *$ \\
\hline BSPN & 163 & 112 & 56.7 & 64.2 & 4.18 & ** & ns & $* *$ \\
\hline Peptide N & 84.1 & 83.0 & 87.4 & 67.7 & 4.47 & $* *$ & ns & $* *$ \\
\hline Amino acid $\mathrm{N}$ & 24.9 & 60.1 & 35.6 & 46.6 & 1.63 & $* *$ & $* *$ & $* *$ \\
\hline NDIN & 96.1 & 97.4 & 107 & 90.4 & 2.62 & $* *$ & ns & $* *$ \\
\hline $\mathrm{ADIN}$ & 68.6 & 69.6 & 76.8 & 64.6 & 1.87 & $* *$ & ns & $* *$ \\
\hline
\end{tabular}

BSN - buffer soluble nitrogen; NPBSN - non protein buffer soluble nitrogen; BSPN - buffer soluble protein nitrogen; NDIN - neutral detergent insoluble nitrogen; ADIN - acid detergent insoluble nitrogen; S - species; W - wilting; SEM - standard error of the mean; ns - not significant; ** significant at $P<0.01 ; *$ significant at $P<0.05$

content, from 915 to 836 and $748 \mathrm{~g} \mathrm{~kg}^{-1}$ of total nitrogen in alfalfa (a decrease by $8.8 \%$ and $18.3 \%$, respectively), and from 959 to 924 and $889 \mathrm{~g} \mathrm{~kg}^{-1}$ total nitrogen in red clover (a decrease by $3.7 \%$ and $7.3 \%$, respectively). The cited authors found that forage species and wilting had a significant effect on the protein/total nitrogen ratio. Guo et al. (2008) reported that the wilting of alfalfa forage for 10 hours, from the dry mater content of 230 to $330 \mathrm{~g} \mathrm{~kg}^{-1}$, decreased the protein nitrogen content by $2.47 \%$ (from 850 to $829 \mathrm{~g} \mathrm{~kg}^{-1}$ of total nitrogen). Considerable differences in protein nitrogen levels in fresh and wilted herbage, noted in the above study, could have resulted from different rates of water loss during wilting, determined by environmental conditions (temperature, humidity, air flow) and by the properties of plant material (percentage shares of leaves and stems, which differ among species, and the growth stage at which the plants were harvested). CAVAllarin et al. (2005) demonstrated that mechanical conditions may limit proteolysis and catabolism of essential amino acids by reducing field wilting time. The content of BSN and its fractions and the concentrations of NDIN and ADIN varied between the analyzed legume species $(p<0.01)$.

The wilting of alfalfa and red clover herbage affected the concentration of the BSN fraction, and in particular NPBSN, as well as free amino acid nitrogen.The wilting process had no effect on the content of soluble proteins, NDIN and ADIN. The legume species $\mathrm{x}$ wilting interaction $(p<0.01)$ was noted with respect to all soluble and insoluble nitrogen fractions (except for protein nitrogen), which indicates that the nitrogen compounds contained 
in the analyzed forage species differed in their response to wilting. During alfalfa wilting, the content of all soluble nitrogen fractions (BSN) decreased, including soluble proteins (by $32 \%$ ), whereas the concentrations of non-protein nitrogen compounds increased (by 30\%), mostly due to an increase in free amino acid nitrogen (by 140\%), and peptide nitrogen levels remained unchanged. The content of ADIN and NDIN in total nitrogen did not change during alfalfa wilting. During red clover wilting, the BSN content did not change significantly and, unlike in alfalfa, the concentrations of non-protein nitrogen compounds decreased (by 7\%) and soluble protein content increased (by 13\%). A significant increase in free amino acid nitrogen (by 31\%) noted in alfalfa was not reported in red clover, in which a substantial peptide nitrogen loss (by 23\%) was observed. The NDIN and ADIN concentrations decreased in wilted red clover by $15 \%$ and $16 \%$, respectively.

In a study by Guo et al. (2008), the wilting of alfalfa herbage for 10 hours, from the dry matter content of 230 to $330 \mathrm{~g} \mathrm{~kg}^{-1}$, decreased the protein nitrogen content by $2.47 \%$, and increased the non-protein nitrogen content: $\mathrm{N}-\mathrm{NH}_{3}$ by $22.5 \%$ (from 2.8 to $3.43 \mathrm{~g} \mathrm{~kg}^{-1}$ total nitrogen), N-AA by $2.7 \%$ (from 66.5 to $68.3 \mathrm{~g} \mathrm{~kg}^{-1}$ total nitrogen), peptide nitrogen by $23.8 \%$ (from 80 to $99 \mathrm{~g} \mathrm{~kg}^{-1}$ total nitrogen). The cited authors noted a $3 \%$ decrease in buffersoluble protein (from 570 to $554 \mathrm{~g} \mathrm{~kg}^{-1}$ of total nitrogen), a 7\% increase in protein fraction $\mathrm{B}_{2}$ (from 135 to $145 \mathrm{~g} \mathrm{~kg}^{-1}$ of total nitrogen), and a decrease in insoluble nitrogen (from 125 to $103 \mathrm{~g} \mathrm{~kg}^{-1}$ of total nitrogen); the ADIN content increased, whereas the NDIN content decreased.

Wilting and forage species had no influence on total amino acids per $100 \mathrm{~g}$ protein (Table 3). Legume species affected the levels of Thr, Ser, Pro, Cys, Met, Lys $(p<0.01)$, Ala, Val, Trp and His $(p<0.05)$. Alfalfa protein contained higher concentrations of Pro, Cys, Met, Trp and Lys, whereas red clover protein had a higher content of Thr, Ser, Ala, Val, Tyr and Hys. Wilting in the field increased the levels of Pro, Trp $(p<0.01)$ and His $(p<0.05)$, but decreased the Glu content $(p<0.05)$ in both forage species. The concentrations of Thr and Ser increased $(p<0.01)$ in wilted alfalfa and decreased in wilted red clover. The Cys content decreased $(p<0.01)$ in alfalfa protein and increased in red clover protein. The varied effects of wilting on amino acids in red clover and alfalfa protein were confirmed by significant $(p<0.01)$ interactions with regard to Thr, Ser, Pro, Val, Cys, Met, Trp $(p<0.01)$, Leu and Phe $(p<0.05)$.

In an experiment carried out by WiNTERs et al. (2000), percentages of total amino acid nitrogen and free amino acid nitrogen in total nitrogen in the green herbage of hybrid ryegrass (perennial ryegrass $\mathrm{x}$ Italian ryegrass) were $78.6 \%$ and $4.34 \%$, respectively, and after two days of ensiling under natural moisture conditions the respective values reached $74.6 \%$ and $8.28 \%$. In the present study, the increase in free amino acid nitrogen noted during wilting over similar periods of time (from $2.49 \%$ to $6.01 \%$ total nitrogen in alfalfa, and from $3.56 \%$ to $4.66 \%$ total nitrogen in red clover) indicates a hi- 
Composition of alfalfa and red clover protein (g $100 \mathrm{~g}^{-1}$ crude protein)

\begin{tabular}{|c|c|c|c|c|c|c|c|c|}
\hline \multirow{2}{*}{ Amino acid } & \multicolumn{2}{|c|}{ Alfalfa } & \multicolumn{2}{|c|}{ Red clover } & \multirow{2}{*}{ SEM } & \multicolumn{3}{|c|}{ Treatment } \\
\hline & fresh & wilted & fresh & wilted & & $\mathrm{S}$ & $\mathrm{W}$ & $\mathrm{SxW}$ \\
\hline Asp & 14.6 & 12.88 & 15.08 & 14.17 & 0.385 & ns & ns & $\mathrm{ns}$ \\
\hline Thr & 1.71 & 3.73 & 3.61 & 3.56 & 0.259 & $* *$ & $* *$ & $* *$ \\
\hline Ser & 1.59 & 3.88 & 4.23 & 3.93 & 0.328 & $* *$ & $* *$ & $* *$ \\
\hline Glu & 10.16 & 6.83 & 11.03 & 6.97 & 0.194 & $\mathrm{~ns}$ & $*$ & $\mathrm{~ns}$ \\
\hline Pro & 5.71 & 7.77 & 5.70 & 6.53 & 0.264 & $* *$ & $* *$ & $* *$ \\
\hline Gly & 3.62 & 4.21 & 4.17 & 4.31 & 0.102 & ns & $*$ & $\mathrm{~ns}$ \\
\hline Ala & 4.19 & 4.49 & 4.62 & 4.75 & 0.089 & * & ns & $\mathrm{ns}$ \\
\hline Val & 4.10 & 5.02 & 5.35 & 4.83 & 0.158 & $*$ & ns & $* *$ \\
\hline Cys & 1.82 & 1.76 & 0.86 & 1.29 & 0.119 & $* *$ & $* *$ & $* *$ \\
\hline Met & 1.93 & 1.52 & 0.89 & 1.43 & 0.115 & $* *$ & ns & $* *$ \\
\hline Ile & 4.83 & 3.82 & 4.60 & 3.99 & 0.082 & ns & ns & $\mathrm{ns}$ \\
\hline Leu & 6.86 & 6.72 & 5.71 & 7.19 & 0.220 & ns & ns & * \\
\hline Tyr & 3.50 & 3.57 & 4.05 & 5.57 & 0.343 & * & ns & $\mathrm{ns}$ \\
\hline Phe & 3.88 & 3.71 & 3.34 & 4.75 & 0.201 & ns & ns & $*$ \\
\hline $\operatorname{Trp}$ & 1.33 & 1.37 & 0.94 & 1.58 & 0.071 & $*$ & $* *$ & $* *$ \\
\hline Lys & 4.75 & 4.93 & 3.71 & 3.94 & 0.189 & $* *$ & ns & $\mathrm{ns}$ \\
\hline His & 3.06 & 3.17 & 3.22 & 3.58 & 0.069 & * & * & $\mathrm{ns}$ \\
\hline Arg & 4.40 & 3.65 & 3.74 & 3.52 & 0.152 & ns & ns & $\mathrm{ns}$ \\
\hline Total & 82.04 & 83.03 & 84.85 & 85.89 & 15.6 & ns & ns & $\mathrm{ns}$ \\
\hline
\end{tabular}

$\mathrm{S}$ - species; W - wilting; SEM - standard error of the mean; ns - not significant; ** significant at $P<0.01 ;{ }^{*}$ significant at $P<0.05$

gher proteolytic potential of alfalfa and more effective proteolysis-inhibiting mechanism in red clover. ARRIGo (2006) compared different methods of grass and clover mixture conservation, reporting the highest deviation from the initial total amino acid content in the protein of field-dried forage. According to the cited author, a decrease in amino acid levels was due to leaf loss during the mechanical treatment (cutting and tedding repeated four times). Amino acid loss in the dry matter of field-dried forage, compared with fresh forage, reached $14 \%$ and $7 \%$ in forage harvested at the early and late stage of maturity, respectively $(\mathrm{p}=0.99)$.

In our study, changes in amino acid concentrations did not result from changes in the protein content of leaves and stems caused by mechanical loss, as confirmed by the absence of differences in the total nitrogen content. The changes were most likely due to protein catabolism that occurs in plant cells until the dry matter content reaches 40\% (JARRIGE et al., 1995). 
Guo et al. (2008) reported that the concentrations of essential amino acids were higher $(p<0.05)$ in wilted alfalfa than in fresh alfalfa herbage. In a study of CAVALLARIN et al. (2005), the total amino acid content of sainfoin in herbage was not significantly affected by wilting and mechanical conditioning. Significant differences were observed in the levels of individual amino acids - wilting caused an increase in the concentrations of Asp and Pro and a decrease in the content of Leu, Lys and Arg. ARRIGo (2006) demonstrated that Lys was most susceptible to degradation, in particular in forages harvested at early stages of maturity; three methods of drying, i.e. control drying, drying in the barn and drying in the field, caused Lys degradation in $19 \%, 28 \%$ and 32\%, respectively. Met, Phe and Leu were most resistant to changes during the drying. In our study, the Pro content increased, whereas the levels of Asp, Lys and Arg remained unchanged. The observed increase in Pro and decrease in Glu could have resulted from the fact that Pro is synthesized by transamination of ornithine or reduction of glutamic acid in the presence of alpha-Ketoglutaric acid. An increase in Pro and Leu as well as a decrease in Arg were also reported by Ashbell et al. (1986) and SEYFARTH et al. (1989), as cited in CAVALLARINet al. (2005). According to the above authors, amino acid (in particular Lys) losses are largely determined by the wilting time and temperature. ARRIGo (2006) noted the highest decrease in Lys during the drying. In our experiment, the Lys content did not decrease during the wilting, most likely because the swath was tedded only once, at a relatively high moisture content of the herbage. This suggests that the Lys loss results mostly from the leaf protein loss. In addition, in our study, the sward was cut at the beginning of flowering. According to ARRIGo (2006), forages harvested at late stages of maturity are characterized by smaller amounts of leaves and a slightly increased initial amino acid content in dry matter; they also dry at a faster rate and, consequently, are less prone to proteolysis.

\section{CONCLUSION}

Wilting in the field to the $40 \%$ dry matter content (the swath was tedded once) did not reduce the total nitrogen content of alfalfa and red clover herbage, but significant changes in the composition of nitrogen fractions were observed between cutting and ensiling. Wilting affected the concentration of the BSN fraction, in particular NPBSN, and free amino acid nitrogen. The nitrogen fractions of the analyzed forage species differed in their response to wilting. During alfalfa wilting, the soluble protein content decreased and the concentrations of non-protein nitrogen compounds increased, mostly due to an increase in free amino acid nitrogen. A reverse trend was observed during red clover wilting, in which the concentrations of non-protein nitrogen compounds decreased and soluble protein content increased. A significant in- 
crease in free amino acid nitrogen was not reported, while a peptide nitrogen loss was observed. NDIN and ADIN concentrations decreased only in red clover.The wilting of alfalfa and red clover increased the ratio of peptide-bound to free amino acids, but had no adverse effect on the amino acid profile of protein. The concentrations of essential amino acids that limit milk protein synthesis, i.e. Lys, Met, His and Arg, did not decrease.

Legume wilting in the field contributes to an increase in the concentrations of soluble nitrogen in the plant material intended for ensiling. However, due to an increase in the osmolarity within plant cells and a decrease in buffering capacity, it could restrain changes in nitrogen fractions during the ensiling process.

\section{REFERENCES}

AOAC. 2005. Official methods of analysis. $15^{\text {th }}$ ed. Assoc. Official. Anal. Chem. Washington. DC. USA

Arrigo Y. 2006. Influence du cycle, du state et du mode de conservation sur la teneur en acides amines des fourrages. Rev. Suisse Agric., 38: 247-255.

Ashbell G., Theune H.H., Skran D. 1986. The influence of wilting on wheat silage. Agronomie, 6: 459-462. dx.DOI.org/10.1051/agro:19860506

Cavallarin L., Antoniazzi S., Borreani G., Tabacco E. 2005. Effects of wilting and mechanical conditioning on proteolysis in sainfoin (Onobrychis vicii folia Scop) wilted herbage and silage. J. Sci. Food Agr., 85: 831-838. DOI: 10.1002/jsfa.2022

Dawson L.E.R., Ferris C.P., Steen R.W.J., Gordon F.J., Kilpatrick D.J. 1999. The effects of wilting grass before ensiling on silage intake. Grass Forage Sci., 54: 237-247. DOI: 10.1046/j. 1365-2494.1999.00176.x

Guo X.S., Ding W.R., Han J.G., Zhou H. 2008. Characterization of protein fractions and amino acids in ensiled alfalfa treated with different chemical additives. Anim. Feed Sci. Tech., 142: 89-98. DOI: :10.1016/j.anifeedsci.2007.07.005

Givens D.I., Rulquin H. 2004. Utilization by ruminants of nitrogen compounds in silage-based diets. Anim. Feed Sci.Tech., 114: 1-18. DOI: 10.1016/j.anifeedsci.2003.09.005

Halasińska A.G., Trzcińska M., Sieliwanowicz B. 2001. Polyphenolnoxidase from Gliocladiumvirens. Pol. J. Food Nutr. Sci., 10/51 (1): 25-30.

Hedqvist H., UdÉn P. 2006. Measurement of soluble protein degradation in the rumen. Anim. Feed Sci. Tech., 126: 1-21. DOI:10.1016/j.anifeedsci.2005.05.011.

Jarrige R., Grenet E., Demarquilly C.,Besle J.-M. 1995. Nutrition des ruminants domestiques, ingestion et digestion. INRA Edition, Paris, 48-52.

McDonald P., Henderson A.R. 1962. Buffering capacity of herbage samples as a factor in ensilage. J. Sci. Food. Agric., 13: 395-400

McDonald P., Henderson A.R., Heron S.J.E. 1991. The Biochemistry of silage. $2^{\text {nd }}$ Edition, Chalcombe publications, Marlow Bucks, UK.

Messman M.A., Weiss W.P., Koch M.E. 1994. Changes in total and individual proteins during drying, ensiling, and ruminal fermentation of forages. J. Dairy Sci., 77: 492-500.

Muck R.E. 1988. Factors influencing silage quality and their implications for management. J. Dairy Sci., 71: 2992-3002.

Papadopoulos Y.A., McKersie B.D. 1983. A comparison of protein degradation during wilting and ensiling of six forage species. Can. J. Plant Sci., 63: 903-912.

Purwin C., B. Pysera, A. Sederevičius, S. Makauskas, A. Traidaraitė, K. Lipiński. 2010. Effect 
of silage made from different plant raw materials with the addition of fermentation inhibitor on the production results of dairy cows. Vet. Ir Zoot., 51(73): 44-51.

Purwin C., Pysera B., Żuk-Go€aszewska K., Antoszkiewicz Z., Go€aszewski J., FijaŁkowska M., LIPIŃsKI K. 2011. Fermentation and proteolysis during the ensilage of wilted and unwilted diploid and tetraploid red clover. J. Cent. Europ. Agric., 12(1): 179-194. DOI: 10.5513/ JCEA01/12.1.897

Seyfarth W., Knabe O., Weise G. 1989. Changes in the N-fraction of green fodder during wilting and ensiling. 1. Changes in the $N$-fraction of the plant material during wilting in swath. Arch. Anim. Nutr., 39: 751-761.

Slottner D., Bertilsson J. 2006. Effect of ensiling technology on protein degradation during ensilage. Anim. Feed Sci. Tech., 127: 101-111.

Thomas T.A. 1977 An automated procedure for the determination of soluble carbohydrates in herbage. J. Sci. Food Agric., 28: 639-642.

VAn Soest P.J., Robertson J.B., Lewis B.A. 1991. Methods for dietary fiber, neutral detergent fiber and nonstarch polysaccharides in relation to animal nutrition. J. Dairy Sci., 74: 3583-3597

Winters A.L., Cockburn J.E., Dhanoa M.S., Merry R.J. 2000. Effects of lactic acid bacteria in inoculants on changes in amino acid composition during ensilage of sterile and nonsterile ryegrass. J. Appl. Microbiol., 89: 442-451.

Winters A.L., Lloyd J.D., Jones R., Merry R.J. 2002. Evaluation of a rapid method for estimating free amino acids in silages. Anim. Feed Sci. Tech., 99: 177-187.

Żuk-Go€aszewska K., Purwin C., Pysera B., Wierzbowska J., Go€szewski J. 2010. Yields and quality of green forage from red clover di- and tetraploid forms. J. Elem., 15(4): 757-770. DOI:10.5601/jelem.2010.15.4.757-770 